\title{
CSF1 wt Allele
}

National Cancer Institute

\section{Source}

National Cancer Institute. CSF1 wt Allele. NCI Thesaurus. Code C49774.

Human CSF1 wild-type allele is located within 1p21-p13 and is approximately $19 \mathrm{~kb}$ in length. This allele, which encodes macrophage colony-stimulating factor 1 protein, is involved in the production, differentiation, and function of macrophages. 